\title{
Acute gastric volvulus in a patient with trisomy 21
}

\author{
Kota Arima ${ }^{1,2}$, Daisuke Hashimoto ${ }^{2}$, Noboru Takata ${ }^{1}$, Yasuro Doi ${ }^{1}$, Ichiro Yoshinaka ${ }^{1}$, Kazunori Harada ${ }^{1}$ \\ and Hideo Baba ${ }^{2 *}$
}

\begin{abstract}
Acute gastric volvulus is a torsion of the stomach by more than $180^{\circ}$ and a life-threatening condition. We present a 50-year-old male patient with acute abdominal pain who has Down syndrome/trisomy 21. Computed tomography showed a significant distended stomach with features of a severe gastric volvulus. Emergency operation in form of reduction and gastropexy was performed. We are not aware of any similar cases published in the English literature, where as gastric volvulus occurred in a patient with Down syndrome.
\end{abstract}

Keywords: Gastric volvulus; Down syndrome; Emergency operation

\section{Background}

Acute gastric volvulus is a rare but potentially lifethreatening condition due to possible gastric necrosis. The cause of this disease is surmised to the insufficient fixation by intraperitoneal visceral ligaments. There have been a number of case reports on volvulus cases in the past; however, a case of it with a chromosomal abnormality as one of the possible major causes has never published [1-5]. We herein report a rare case of acute severe gastric volvulus that occurred in a patient with Down syndrome.

\section{Case presentation}

A 50-year-old male patient, with Down syndrome/trisomy 21 derived from a 14/21 Robertsonian translocation, was presented at our hospital who suffered from severe abdominal pain. He showed a severe intellectual disability and had a megacolon. Abdominal examination revealed abdominal distention but did not indicate any muscular defense. Laboratory investigations showed elevations in the white blood cell count $\left(16,900\right.$ cells $\left./ \mathrm{mm}^{3}\right)$, neutrophil fraction (91.3\%), and C-reactive protein (7.3 $\mathrm{mg} / \mathrm{dl})$. Contrast-enhanced computed tomography (CT) showed a significant distended and twisted stomach (Figure 1a,b), suggesting a diagnosis of mesenteroaxial gastric volvulus.

\footnotetext{
* Correspondence: hdobaba@kumamoto-u.ac.jp

${ }^{2}$ Department of Gastroenterological Surgery, Kumamoto University Graduate School of Medical Sciences, 1-1-1 Honjo, Chuo-ku, Kumamoto 860-8556, Japan

Full list of author information is available at the end of the article
}

As a nasogastric tube or a gastroscope was unable to reach the stomach, it was opted to immediately perform an emergency operation. Due to the severe distended stomach, adequate intra-abdominal space was not available so that laparoscopic operation was no option for this patient as report in other cases [6,7]. Laparotomy showed a large, distended, and twisted stomach (Figure 1c and 2). The stomach was successfully repositioned, and gastropexy in combination with the Coffey method was performed (Figure 3).

\section{Discussion}

Gastric volvulus was reported to be more likely to be complicated by wandering spleen, diaphragmatic eventration, and malrotation of the intestine [8-11]. Even though major gastrointestinal malformation, such as congenital esophageal atresia, has been reported to occur in Down syndrome patients, we are not aware of cases of gastric volvulus published in the English literature that occurred in a patient with Down syndrome $[12,13]$. Primary gastric volvulus is related to the lack of fixation by the ligaments which exist between a stomach and other organs. These gastric ligaments were significantly extended in this patient, and this malformation was most likely a major cause of gastric volvulus. If the gastric ligaments are extended or absent, the stomach may rotate easily. As they were significantly extended in this patient, this malformation was most likely a major cause of gastric volvulus in our patient. Furthermore, even though there are some reports of deficiency of the gastric ligaments, there is no report about possible reasons of this deficiency and extension of it $[11,14,15]$. It is 


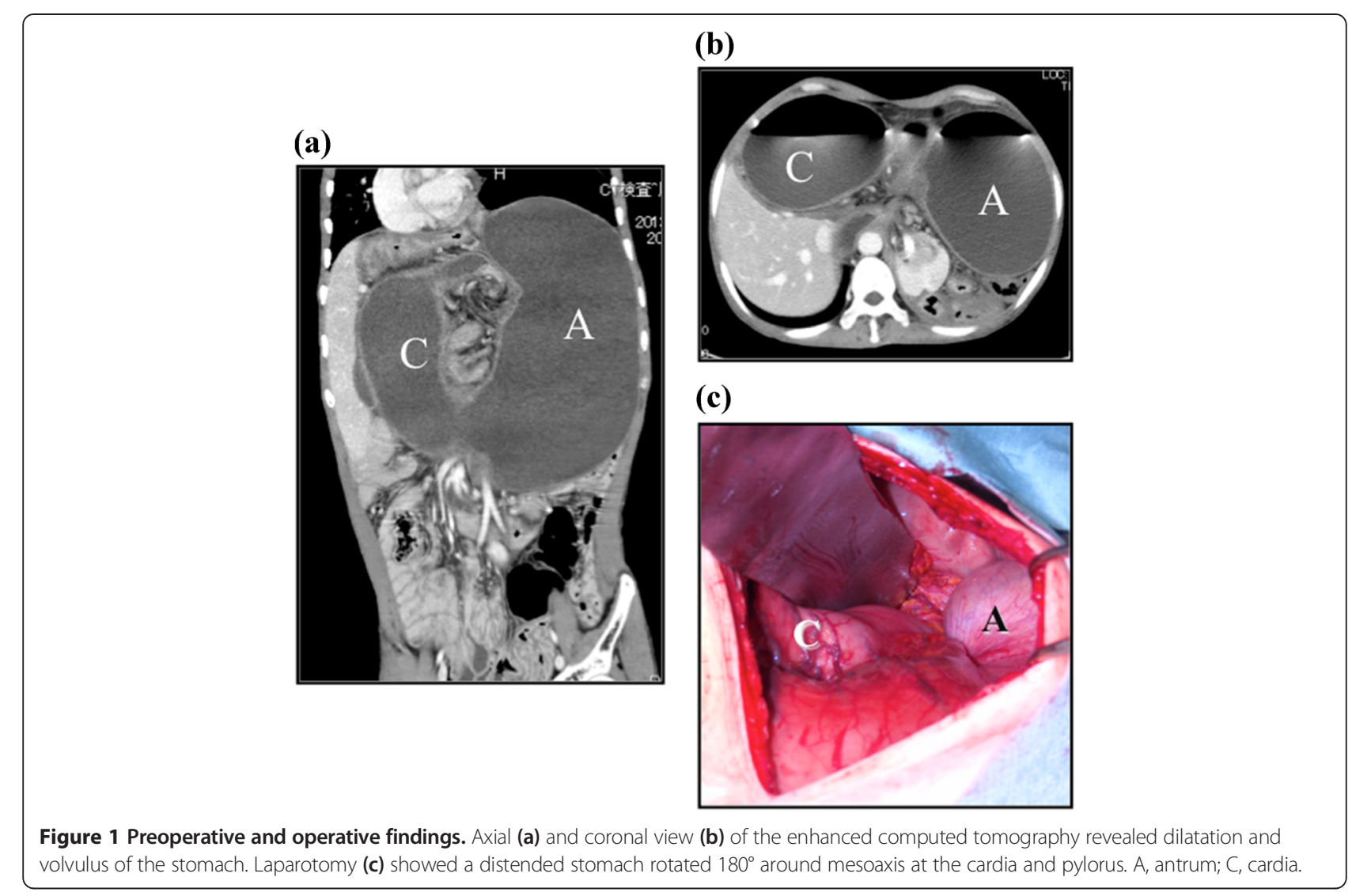

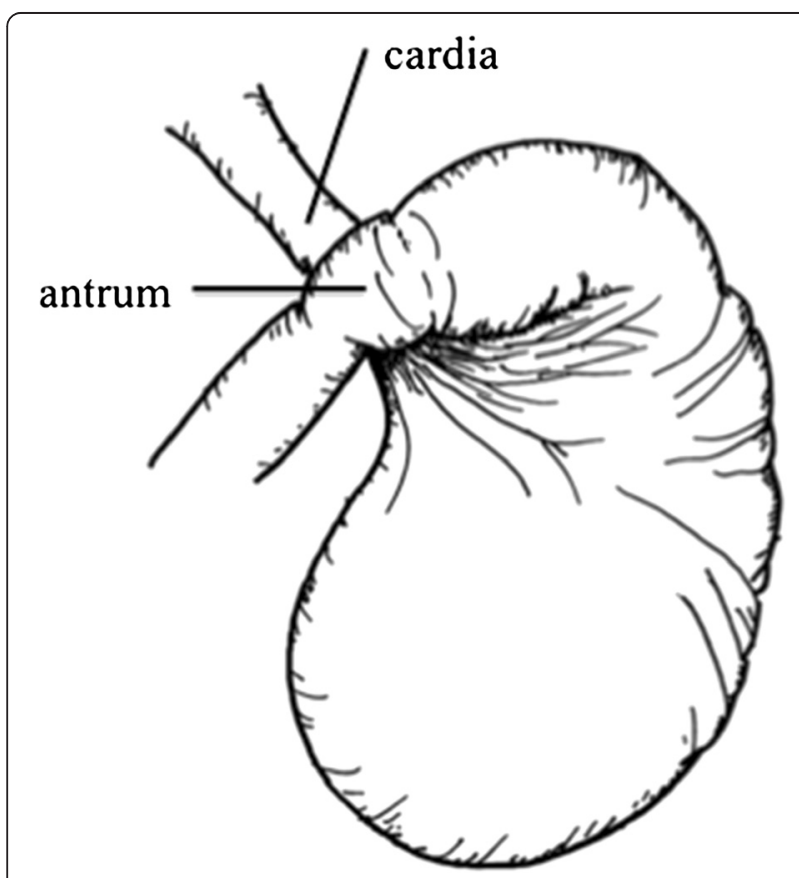

Figure 2 Preoperative scheme. A scheme shows the state of the stomach.

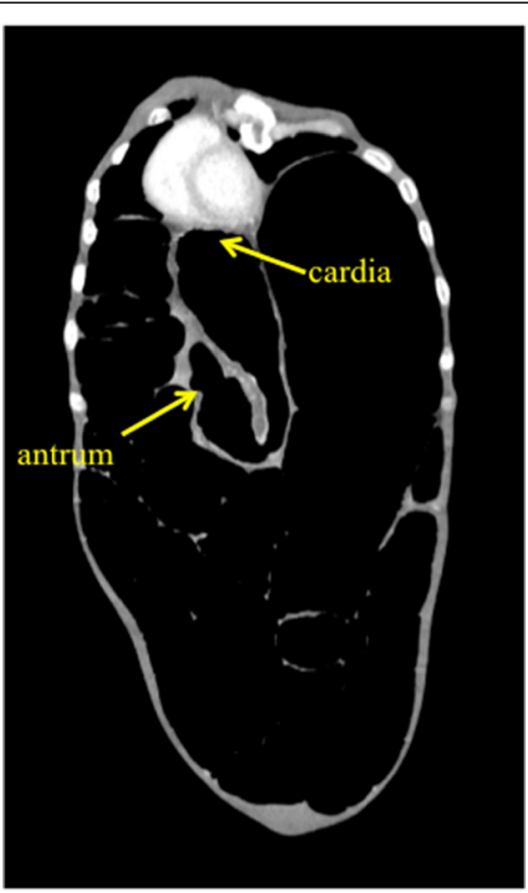

Figure 3 Postoperative findings. The coronal view of the enhanced $C T$ revealed the recovery of gastric volvulus after surgery. 
therefore important to be aware of the possible occurrence of gastric volvulus in the patients with trisomy 21 .

\section{Conclusions}

Gastric volvulus is a rare but life-threatening condition unless diagnosing and treating rapidly. We could save the patient of the gastric volvulus due to early diagnosis and surgery.

\section{Consent}

Written informed consent was obtained from the patient for publication of this case report and any accompanying images. A copy of the written consent is available for review by the Editor in Chief of this journal.

\section{Abbreviations \\ CT: computed tomography.}

Competing interests

The authors declare that they have no competing interests.

\section{Authors' contributions}

$\mathrm{KA}$ and $\mathrm{DH}$ participated in the conception, design, and analysis of this case report and drafted the manuscript. YD, NT, and IY participated in the statistical analysis and revised it. $\mathrm{KH}$ and $\mathrm{HB}$ conceived of the study and participated in its design and coordination and helped to draft the manuscript. All authors read and approved the final manuscript.

\section{Acknowledgements}

We thank Ms. Anett Iwamoto, who was employed at Kumamoto University, for amending the manuscript.

\section{Author details}

'Department of Surgery, Amakusa Regional Medical Center, 854-1 Jikiba, Kameba-machi, Amakusa, Kumamoto 863-0046, Japan. ${ }^{2}$ Department of Gastroenterological Surgery, Kumamoto University Graduate School of Medical Sciences, 1-1-1 Honjo, Chuo-ku, Kumamoto 860-8556, Japan.

Received: 25 August 2014 Accepted: 24 November 2014

Published online: 16 January 2015

\section{References}

1. Tillman BW, Merritt NH, Emmerton-Coughlin H, Mehrotra S, Zwiep T, Lim R. Acute gastric volvulus in a six-year-old: a case report and review of the literature. J Emerg Med. 2014; 46(2):191-6. doi:10.1016/j.jemermed.2013.08.046.

2. Jamil LH, Huang BL, Kunkel DC, Jayaraman V, Soffer EE. Successful gastric volvulus reduction and gastropexy using a dual endoscope technique. Case Rep Med. 2014; 2014:136381. doi:10.1155/2014/136381.

3. Vasilevska M, Ivanovska E, Kubelka Sabit K, Sukarova-Angelovska E, Dimeska $\mathrm{G}$. The incidence and type of chromosomal translocations from prenatal diagnosis of 3800 patients in the Republic of Macedonia. Balkan J Med Genet. 2013; 16(2):23-8. doi:10.2478/bjmg-2013-0027.

4. Pazarbasi A, Demirhan O, Alptekin D, Ozgunen F, Ozpak L, Yilmaz MB, Nazlican E, Tanriverdi N, Luleyap U, Gumurdulu D. Inheritance of a chromosome 3 and 21 translocation in the fetuses, with one also having trisomy 21, in three pregnancies in one family. Balkan J Med Genet. 2013; 16(2):91-6. doi:10.2478/bjmg-2013-0039.

5. Dreux S, Olivier C, Dupont JM, Leporrier N, Study G, Oury JF, Muller F. Maternal serum screening in cases of mosaic and translocation Down syndrome. Prenat Diagn. 2008; 28(8):699-703. doi:10.1002/pd.2051.

6. Wolfgang R, Lee JG. Endoscopic treatment of acute gastric volvulus causing cardiac tamponade. J Clin Gastroenterol. 2001; 32(4):336-9.

7. Siu WT, Yau KK, Luk YW, Law BK, Li MK. Endoscopic reduction of a gastric volvulus associated with a paraesophageal hernia. Endoscopy. 2005; 37(8):787. doi:10.1055/s-2005-870145.

8. Karande TP, Oak SN, Karmarkar SJ, Kulkarni BK, Deshmukh SS. Gastric volvulus in childhood. J Postgrad med. 1997; 43(2):46-7.
9. Mayo A, Erez I, Lazer L, Rathaus V, Konen O, Freud E. Volvulus of the stomach in childhood: the spectrum of the disease. Pediatr Emerg Care 2001; 17(5):344-8.

10. Spector JM, Chappel J. Gastric volvulus associated with wandering spleen in a child. J Pediatr Surg. 2000; 35(4):641-2.

11. Cameron AE, Howard ER. Gastric volvulus in childhood. J Pediatr Surg. 1987; 22(10):944-7.

12. Singh MV, Richards C, Bowen JC. Does Down syndrome affect the outcome of congenital duodenal obstruction? Pediatr Surg Int. 2004; 20(8):586-9. doi:10.1007/s00383-004-1236-1.

13. Korenberg JR, Chen XN, Schipper R, Sun Z, Gonsky R, Gerwehe S, Carpenter N, Daumer C, Dignan P, Disteche C, Graham JM, Hudgins L, McGillivray B, Miyazaki K, Ogasawara N, Park JP, Pagon R, Pueschel S, Sack G, Say B, Schuffenhauer S, Soukup S, Yamanaka T. Down syndrome phenotypes: the consequences of chromosomal imbalance. Proc Nat Acad Sci U S A. 1994; 91(11):4997-5001.

14. Odaka A, Shimomura K, Fujioka M, Inokuma S, Takada S, Yamada H, Ishida H, Murata N, Idezuki Y. Laparoscopic gastropexy for acute gastric volvulus: a case report. J Pediatr Surg. 1999; 34(3):477-8.

15. Basaran UN, Inan M, Ayhan S, Ayvas S, Ceylan T, Pul M. Acute gastric volvulus due to deficiency of the gastrocolic ligament in a newborn. Eur J Pediatr. 2002; 161(5):288-90.

\section{Submit your manuscript to a SpringerOpen ${ }^{\circ}$ journal and benefit from:}

- Convenient online submission

- Rigorous peer review

- Immediate publication on acceptance

- Open access: articles freely available online

- High visibility within the field

- Retaining the copyright to your article

Submit your next manuscript at $>$ springeropen.com 